Лю Фань, Аспірант кафедри „, Теорія та історія музичного виконавства" Національної музичної академії України ім. П.І. Чайковського

тел. (073) 045 - 98 - 51 e-mail: lufanukraine@gmail.com

\title{
СТАРИЙ СУЧАСНИЙ ПОГЛЯД НА ФОРТЕПІАНО У ТВОРЧОСТІ ІГОРЯ ЩЕРБАКОВА
}

Мета статті. У статті виявлено специфіку трактування фортепіано у творчості І. Щербакова та ії зв’язки із традиційними образами інструмента. Методологія дослідження полягає у використанні цілісного аналізу музичного твору. Застосування культурологічного та компаративного методів дозволяє простежити еволюцію співучого i ностальгійного образів фортепіано та їх відбиття у творчості I. Щербакова. Звернення до структурноаналітичного методу дослідження, у контексті заявленої проблематики, створює можливість щодо відповідного структурування теоретичного матеріалу та утвердження загальних висновків наукової розвідки. Активно використовуються у практичному науково-дослідницькому значенні методи емпіричної природи, а саме спостереження та узагальнення. Наукова новизна. У статті вперше проаналізовано особливості трактування образу фортепіано сучасним українським композитором I. Щербаковим. Уперше висвітлено новаторське відбиття традиції „співу на фортепіано" в умовах постмодерністської культурної ситуації в українській музиці початку XXI ст. Висновки. У творчості I. Щербакова актуалізується давня традиція погляду на фортепіано як на співучий інструмент. В умовах постмодерністської культурної ситуації ця традиція набуває особливої ностальгійної конотації. Образ фортепіано І. Щербакова складається 3 двох основних взаємопов'язаних компонентів: образу фортепіано як співучого інструмента i ностальгійного образу фортепіано як 
символу „золотого віку” музичного мистецтва, символу високої культури взагалі. У формуванні цих образів фортепіано відіграють важливу роль як художньо-стильові, так і культурно-соціальні чинники. Ностальгійний образ фортепіано, що пов'язується у I. Щербакова 3 образом „співучого фортепіано” - продуктом романтичної епохи, є характерним для українського та світового мистецтва сьогодення.

Ключові слова: Ігор Щербаков, фортепіано, спів на фортепіано, образ інструмента, ностальгійний образ фортепіано, сучасна українська фортепіанна музика, постмодернізм.

Лю Фань, аспирант кафедры „Теория и история музыкального исполнительства" Национальной музыкальной академии Украины им. П.И. Чайковского

\section{Старый современный взгляд на фортепиано в творчестве Игоря Щербакова}

Цель статьи. В статье выявляется специфика трактовки фортепиано в творчестве И. Щербакова и её связи с традиционными образами инструмента. Методология исследования заключается в использовании целостного анализа музыкального произведения. Применение культурологического и компаративного методов позволяет проследить эволюцию певучего и ностальгического образов фортепиано и их преломление в творчестве И. Щербакова. Обращение к структурноаналитическому методу исследования, в контексте заявленной проблематики, создаёт возможность определённого структурирования теоретического материала и утверждения общих выводов научной работы. Активно используются в практическом научно-исследовательском значении методы эмпирической природы, а именно наблюдение и обобщение. Научная новизна. В статье впервые проанализированы особенности трактовки образа фортепиано современным украинским композитором И. Щербаковым. Впервые освещено новаторское преломление традиции „пения на фортепиано” в условиях постмодернистской культурной ситуации в украинской музыке начала XXI в. Выводы. В творчестве И. Щербакова актуализируется давняя традиция взгляда на фортепиано как на певучий инструмент. В условиях постмодернистской культурной ситуации эта традиция приобретает 
особую ностальгическую коннотацию. Образ фортепиано И. Щербакова состоит из двух основных взаимосвязанных компонентов: образа фортепиано как певучего инструмента и ностальгического образа фортепиано как символа „золотого века” музыкального искусства, символа высокой культуры вообще. В формировании этих образов фортепиано играют важную роль как художественно-стилевые, так и культурно-социальные факторы. Ностальгический образ фортепиано, связываемый у И. Щербакова с образом „певучего фортепиано” - продуктом романтической эпохи, характерен для современного украинского и мирового искусства.

Ключевые слова: Игорь Щербаков, фортепиано, пение на фортепиано, образ инструмента, ностальгический образ фортепиано, современная украинская фортепианная музыка, постмодернизм.

Lu Fan, postgraduate of „Theory and history of musical performance" chair from P. Tchaykovsky National Music Academy of Ukraine

Old modern look at the piano in the works by Igor Shcherbakov

Purpose of the article. The article reveals specifics of the interpretation of the piano in the works of I. Shcherbakov and its connection with the traditional images of the instrument. The research methodology lies in using of the musical work. The application of cultural and comparative methods makes it possible to trace the evolution of the singing and nostalgic images of the piano and their embodiment in the work of I. Shcherbakov. The opportunity certain structuring of theoretic material and approving the general conclusions of the scientific work is made by appealing to the structurally analytical method of the research, at the context declared problems. The methods observation and generalization, as the methods of empirical nature, are actively employing in practice scientifically investigative significance in represented disquisition. Scientific novelty. In the article peculiarities of the interpretation of the piano image by the modern Ukrainian composer I. Shcherbakov are analyzed for the first time. For the first time the innovative embodiment of the tradition of ,singing on the piano" in the postmodern cultural situation in Ukrainian music of the early $21 \mathrm{st}$ century was pointed out. Conclusions. In the work of I. Shcherbakov the 
old tradition of interpreting the piano as a singing instrument is actualized. In the postmodern cultural situation, this tradition takes on a special nostalgic connotation. The image of I. Shcherbakov's piano consists of two main interrelated components: the image of a piano as a musical instrument and a nostalgic image of a piano as a symbol of the ,golden age" of musical art, a symbol of high culture in general. In the formation of these piano images an important role is played both by stylistic and cultural-social factors. The nostalgic image of the piano, associated with I. Shcherbakov with the image of the „singing piano" - a product of the romantic era, is characteristic of modern Ukrainian and world art.

The key words: Igor Shcherbakov, piano, singing on the piano, image of the instrument, nostalgic image of the piano, modern Ukrainian piano music, postmodernism.

Постановка проблеми. Ігор Щербаков є одним із провідних сучасних українських композиторів. Значне місце у творчості I. Щербакова займають твори для фортепіано. Ним написані три фортепіанні концерти (1996, 2006, 2013), „Баркарола” для фортепіано 3 оркестром (2005), „Motus”/,Рухи” для фортепіано 3 оркестром (2017), три сонати (1980, 1993, 2008), „Баркарола” для двох фортепіано, „Дитячий альбом” для фортепіано. Аналіз фортепіанної творчості І. Щербакова $є$ важливим для розуміння сучасного образу фортепіано, сформованого в українській музиці на початок XXI ст.

Незважаючи на значну популярність творів I. Щербакова серед музичної аудиторії i виконавців, його творчість, особливо фортепіанна, все ще чекає на своє повноцінне дослідження.

Актуальність статті зумовлена недостатньою вивченістю фортепіанної творчості українського композитора попри безсумнівне його значення для формування сучасного українського національного звукового образу фортепіано.

Огляд літератури. Творчості І. Щербакова присвячені дослідження музикознавців Г. Степанченко [10], О. Скрипника [9], Є. Харченко [12], В. Степурка [11]. У них пропонується загальна характеристика творчості композитора [10], а також на прикладі окремих творів розглянуто характерні стильові риси в контексті актуальних проблем сучасної музичної теорії i практики. Так, 
О. Скрипник звертає увагу на використання I. Щербаковим алеаторичної техніки, В.Степурко досліджує творчий процес композитора за допомогою категорії „мистецької інтроверсіі”, а Є. Харченко виявляє постмодерністські риси у стилістиці композитора.

Мета статті полягає у виявленні специфіки трактування фортепіано у творчості І. Щербакова та піi зв'язків 3 традиційними образами інструмента.

Об'єктом дослідження $\epsilon$ творчість І. Щербакова, а предметом - образ фортепіано у творчості композитора.

Виклад основного матеріалу. Як вказує Г. Степанченко, музика I. Щербакова „відображає багатий спектр його творчого мислення, захоплює особливою енергетикою, пробуджує думку, викликає співпереживання. Композитор уміє розкрити найпотаємніші переживання людини, йому притаманне заглиблення у психологічний світ особистості. Він ніби веде 3 аудиторією невимушений діалог, у якому переплітаються драматичні і ліричні інтонаціі” $[10,363]$. Відзначимо, що одним із найважливіших компонентів цього діалогу з боку композитора $\epsilon$ виразні назви, які розкривають ідейний зміст твору та спрямовують образні асоціації слухача.

Так, усім п’ятьом камерним симфоніям І. Щербакова дано короткі, але ємні заголовки: № 1 - „Покаянний стих” (1989), № 2 „Aria Passione” (1992), № 3 - „Aria Passione - 2” (2000) , № 4 „Dreamstrings” (2001), № 5 - „Warum?” (2002). Серед фортепіанних творів особливу увагу в цьому відношенні привертають Соната № 2 „Романтична елегія для домашнього музикування” (1993), твір під назвою „Liebes Tod. Післямова” (1995) та Соната № 3 „Piano Gesang" (2008). Заголовки перших двох фортепіанних творів свідчать про неоромантичні та постмодерністські стилістичні устремління композитора. С. Харченко зазначає, що у назві „Liebes Tod. Післямова” „визначені драматургічні особливості композиції, а основним композиційним прийомом твору стає „гра стильовими моделями задля створення трагедійної концепції” $[12,172]$. Як історико-стильові музичні символи у творі використано відомі цитати, лейтінтонаціі, теми-символи 3 творів Р. Вагнера, Л. ван Бетховена, Ф. Ліста. 
Соната № 3 має особливе значення для аналізу особливостей погляду сучасного українського композитора на фортепіано, тому що в ¥ї заголовку „Piano Gesang” використано саму назву інструмента, що свідчить про прагнення композитора розкрити в даному творі своє ставлення до інструмента, свій особливий образ цього інструмента. Особливу увагу привертає двомовність назви. Таким чином зводиться до мінімуму можливість граматичних відносин між словами „Ріano” (у перекладі 3 англійської „фортепіано”) та „Gesang” (у перекладі 3 німецької „спів”). Підкреслюється самостійна значимість кожного слова, відмінність музичних феноменів, що визначаються цими словами, і тим самим акцентується ідея сплаву „Piano” i „Gesang” в єдине ціле, як мета важко досяжна і неймовірно цінна для автора. Очевидно, що якби ці слова були б викладені однією мовою (наприклад, „Piano Singing” або „Klavier Gesang”), було б нівельовано ефект максимального підкреслення різної природи цих явищ, труднощів $\mathrm{i}$ трансцендентності їх сполуки.

Цей ефект ми спостерігаємо і в початковому варіанті назви. Як пише І. Щербаков в анотації до твору, „назва починалась російською «Пиано-Пение»" [13]. I в російському оригіналі ми можемо знайти ті ж особливості з'єднання слів і визначених ними явищ, що проявляються i в англо-німецькому перекладі. Слова розділяються і водночас з'єднуються дефісом, при цьому кожне 3 них подане у називному відмінку, що підкреслює їх рівноцінність, самостійність та інтенцію до зрощення. Присутня й прихована двомовність, тому що назву інструмента „фортепіано” подано в російській транскрипції його англійського аналога („пиано”). Нарешті, ідея сплаву двох таких різних явищ в єдине ціле підкреслюється алітераційною грою слів „пиано” і „пение”.

Звичайно, природно виникає думка про можливість трактування слів „пиано” і „Ріапо” як динамічного відтінку. Однак, такій інтерпретації заголовка п'єси суперечить іiі різноманітна динаміка (від ppp до ffff з усіма проміжними градаціями), а також пояснення самого композитора щодо ідейної суті свого твору: „Ідея в мене була така - я останнім часом слухаю багато сучасних піаністів, намагаюсь не відставати в нових іменах. Чесно кажучи, слухаю набагато більше, ніж нову музику. Так от, сучасний піанізм 3 його майже досконалою вивіреністю кожного звуку <..> втратив 
ту високу духовність i свободу, яку давало нейгаузовськорахманінівсько-оборинське «пение на фортепиано»" [13].

Як бачимо, І. Щербаков відчуває себе спадкоємцем традиції, для котрої характерно „ставлення до фортепіано як до неодмінно виразно-співучого інструмента” [3, 105]. О. Алексєєв називає „спів” на фортепіано однією 3 ,чудових традицій російського та світового музичного мистецтва" [2,77]. Цитуючи Б. Асаф'єва, відомий методист вказує на багатомірність уявлень про спів на фортепіано, який „не можна зводити лише до досягнення співучості звуку. Це поняття органічно включає у себе натхненність виконання, «пошуки в інструментах виразності і тепла, властивих людському голосу»" $[2,77]$.

Одну 3 перших i найзначніших для подальшої історії фортепіанної педагогіки вказівок на необхідність досягнення співучого виконання знаходимо у відомому поясненні I.C. Баха до збірки інвенцій та сінфоній: „Щире повчання, за допомогою якого любителям клавіру <..> вказується ясний спосіб не тільки <..> отримувати хороші [мелодійні] винаходи, ай добре оні проводити, а більш за все - знайти співучу манеру гри i, разом 3 тим, смак до композиції' [5, 139]. Майже через сто років представник „блискучого стилю” першої половини XIX ст. Сигізмунд Тальберг закликає піаністів „«співати грудьми», використовуючи всі можливості інструмента (beaucoup demander a l'instrument)" $[1,127]$. Не менш переконливою є й опублікована вже у середині XX ст. в книжці „Про мистецтво фортепіанної гри” порада Генріха Нейгауза ,усіма силами i, незважаючи на всі перешкоди, <...> домагатися співу, співу і співу" [7, 163].

Видатний виконавець i педагог ілюструє необхідність досягати „співу на фортепіано” стражданнями, яких він зазнає під час виконання фуги I.C. Баха мі мажор 3 II тому ДТК. Звернемо увагу на те, що Г. Нейгауз намагається досягти співучості у поліфонічних творах I.C. Баха, які призначались для виконання на клавесині, інструменті, що значною мірою відрізняється від сучасного фортепіано. Крім того, в останні десятиліття „зростає розуміння того, що уявлення про співучу манеру гри на клавішних інструментах не були тотожними для різних епох, стилів і країн” $[4,212]$. Як вказує О. Безбородько, тільки „у ХІХ столітті, під впливом італійського співу, що виріс із італійської мовної інтонації, 
співучість стала синонімом зв'язної, легатної гри” [4, 218]. Саме принципи такого романтичного виконання, презирливо названого Ф. Бузоні „погонею за зв'язним ідеалом” $[6,70]$, екстраполював Г. Нейгауз на фугу I.C. Баха.

У своєму творі І. Щербаков також утворює ситуацію зіткнення двох багато в чому протилежних стильових сфер. Здавалося б, для вираження ідеї „співу на фортепіано” найкраще підійшов би тематичний матеріал, що відсилає до романтизму, 3 плавним мелодійним рухом i визначеною тональною основою. Однак, композитор використовує серійний принцип звуковисотної організації, який він сам називає „серійною алеаторикою”. Серійна техніка, поява якої пов'язана 3 прагненням позбутися звичних тональних відносин, стала одним 3 найяскравіших маркерів „сучасності” в музиці XX століття.

„Спів на роялі” - символ і квінтесенція виконавської традиції, що походить від романтичного мистецтва XIX ст. Сплавляючи в єдине ціле настільки протилежні в своїй основі і походженні стильові явища, І. Щербаков проявляє себе художником постмодерної доби, для якого „час є не лінеарним, але радіальним” [14].

Як вказує М. Рябоконєва, у постмодернізмі „не тільки музичний час усередині твору, але й історичний час, що втілюється в певних відомих знаках-символах (стиль, тональність, гармонійні комплекси, жанри, форми і т.д.), стає матеріалом композиторського конструювання та творчої гри” [8, 149-150]. У „Piano Gesang” такими знаками-символами, протиріччя між якими відображає i посилює суперечності, що містяться вже в самій назві п’єси, є серійна звуковисотна організація і вказана композитором манера виконання основної мелодії твору, яка, за словами автора, „в цій п’єсі є головним, <...> є «Пением»" [13].

Незважаючи на свою важливість, головна серійно-співуча мелодія займає відносно малий часовий простір у „Piano Gesang”. Проте, тим самим автор підкреслює їі вистражданість і значимість. Твір починається енергійним, ритмічно витонченим висхідним ходом від до-дієз контроктави, який охоплює весь регістровий діапазон інструмента. Утворене в результаті басове дисонансне співзвуччя (чиста кварта + тритон) стає фундаментом для переривчастих, нервових і напружених фігурацій, розвивання яких 
призводить до кульмінаційного вибуху в такті 57. I тільки в такті 58, на гребені попереднього хаотичного розвою з'являється „тон співу” - мі-бемоль першої октави. Він наполегливо повторюється протягом 15 тактів, ніби привертаючи до себе увагу, провіщаючи щось незвичайне. I в 73 такті настає новий, основний розділ п’єси Con anima, molto espressivo. Мелодія, що починається від мі-бемоля, спочатку викладається дуже великими тривалостями - половинками й цілими. Якщо в першій фразі інтерваліка $є$ достатньо вузькою (не більше тритона), то далі інтонаційні ходи розширюються, мелодія стрибає на нону, дециму, зменшену октаву. Їі співуче виконання вимагає надзвичайних зусиль від піаніста. Оточена спочатку тихими, але згодом чимдалі більш посиленими серійними перебираннями, мелодія врешті-решт повністю втрачає свою співучу сторону і трансформується в повторення енергійного початкового заклику. Лише наприкінці твору виникає відгомін теми-співу, позначений ремаркою con tristezza, який складається усього лише з двох нот - мі-бемоль і до на тлі до-дієз мінорного квартсекстакорду. Як пояснює автор, „до-дієз зустрівся 3 мі-бемолем, і то вийшов не конфлікт, а велика туга...” [13].

Як бачимо, ідея „співу на фортепіано”, реалізована автором у творі з драматургічно напруженим розвитком, що залишає після себе відчуття туги й печалі, видається композиторові не просто продовженням традиції, вона явно несе особисту конотацію, висловлює його душевний біль. Зіставляючи відчуття від музики зі словами автора про свій твір i його назву, ми приходимо до висновку, що для І. Щербакова „спів на фортепіано” становить ностальгійний образ-ідеал. Автор сумує за „тим високим, що ми втрачаємо (разом з фортепіанним співом) взагалі в мистецтві - в його сучасній занадто технологізованій оздобленості" [13].

Ностальгійний образ фортепіано, що пов'язується I. Щербаковим з особливим виконавським стилем, проявляється і в характерному для сучасної культури більш загальному сприйнятті інструмента як носія високої традиції, золотий вік якої знаходиться в більш-менш далекому минулому. Якщо у XIX ст. присутність фортепіано в будинку було не тільки ознакою матеріального добробуту сім'ї, але й ознакою іiі прилучення, за допомогою інструмента, до елітарного мистецтва, яке споконвічно було таланом вищих верств суспільства, у XX ст. у сприйнятті 
фортепіано як символу високої культури стала переважати діахронність. Укорінений у попередньому ,романтичному” столітті педагогічний i виконавський репертуар, небачений раніше i визначальний для соціології мистецтва XX ст. розвиток масової культури з іiі наголосом на нові електричні музичні інструменти, сприяли посиленню погляду на класичне фортепіано, вигляд i конструкція якого повністю сформувались також у XIX ст., як на уособлення чогось прекрасного, але такого, що пішло без вороття.

I хоча фортепіано у повній мірі використовувалось представниками авангардного мистецтва, які розширювали його можливості й способи звуковидобування (Джон Кейдж, Джордж Крам), а також залишається одним з головних інструментів джазу і присутне (хоча й частіше у своїх електричних модифікаціях) в попмузиці, все-таки перш за все цей інструмент асоціюється у суспільній свідомості з високою традицією, з класичним минулим музичного мистецтва, яке, в свою чергу, нерозривно пов'язано 3 епохою романтизму, 3 романтичним стилем виконання (звідси ностальгійне визначення „останній романтик”, яким публіка і критики полюбляли протягом XX ст. наділяти піаністів, що їм особливо подобались) і зі „співом на фортепіано”.

Висновки. У творчості І. Щербакова актуалізується давня традиція погляду на фортепіано як на співучий інструмент. В умовах постмодерністської культурної ситуації ця традиція набуває особливої ностальгійної конотації. Образ фортепіано І. Щербакова складається 3 двох основних взаємопов'язаних компонентів: образу фортепіано як співучого інструмента i ностальгійного образу фортепіано як символу „золотого віку" музичного мистецтва, символу високої культури взагалі. У формуванні цих образів фортепіано відіграють важливу роль як художньо-стильові, так і культурно-соціальні чинники. Ностальгійний образ фортепіано, що пов’язується у I.Щербакова з образом „співучого фортепіано” продуктом романтичної епохи, є характерним для українського та світового мистецтва сьогодення.

Перспективи дослідження полягають у розширенні кола творів i авторів, що вивчаються, для подальшого визначення сьогоденного українського образу фортепіано та місця, яке в ньому займає старий, але сучасний погляд на фортепіано як на неодмінно співучий інструмент. 


\section{Список використаних джерел і література:}

1. Алексеев А. Из истории фортепианной педагогики: руководства по игре на клавишно-струнных инструментах (от эпохи Возрождения до середины XIX века). Київ: Музична Україна, 1974. 163 с.

2. Алексеев А. Методика обучения игре на фортепіано. Москва: Музыка, 1978. $288 \mathrm{c}$.

3. Безбородько О. Музыкальное произношение и артикуляция как композиторские средства выразительности // Вісник Харківської державної академії дизайну і мистецтв: зб. наук. ст. Харків: ХДАДМ, 2012. Вип. 15. C. $102-106$.

4. Безбородько О. Особенности и эволюция певучей трактовки клавишных инструментов от И.С. Баха к романтикам // Київське музикознавство. Серія: Культурологія та мистецтвознавство. Київ, 2005. Вип. 18. С. 211-221.

5. Документы жизни и деятельности И.С. Баха / Сост. Х.Й. Шульце, пер. с нем. В. Ерохина. Москва: Музыка, 1980. 271 с.

6. Коган Г. Ферруччо Бузони: пианист. Москва: Советский композитор, 1971. $232 \mathrm{c}$.

7. Нейгауз Г. Об искусстве фортепьянной игры: записки педагога. Москва: Гос. муз. изд-во, 1961.320 с.

8. Рябоконєва М. Музичний неокласицизм як феномен сучасної західноєвропейської культури: дис. ... канд. мистецтвознав.: 26.00.01 „Теорія та історія культури". Київ, 2016. 197 с.

9. Скрыпник А. Феномен алеаторики в творчестве композиторов XX века: эстетико-культурологический аспект // Науковий вісник Національної музичної академії України ім. П.І. Чайковського: зб. наук. ст. Київ, 2009. Вип. 75. С. $155-170$.

10. Степанченко Г. Композитор Ігор Щербаков у сучасному музичному просторі // Українське музикознавство: зб. наук. пр. Київ: НМАУ ім. П.І. Чайковського, 2015. Вип. 41. С. 362-368.

11. Степурко В. „Концерт для флейти та камерного оркестру (пам’яті Олега Ківи)": мистецька інтроверсія // Мистецтвознавчі записки: зб. наук. пр. Київ: Міленіум, 2013. Вип. 24. С. 9-15.

12. Харченко Є. Інтертекстуальність в українській музиці двадцятого століття: інтонація, жанр, стиль: дис. ... канд. мистецтвознав.: 17.00.03 „Музичне мистецтво”. Київ, 2011. 353 с.

13. Щербаков I. Хочу сказати пару слів про „Піано-Гезанг”. Київ [Рукопис]. 14. Rochberg G. String Quartet No. 3: [liner note to LP record]. - Nonesuch Records № 71283, 1973. 


\section{References:}

1. Alekseyev, A. (1974). From the history of the piano pedagogy: manuals for playing the key-string instruments (from the Renaissance to the middle of $19^{\text {th }}$ century). Kyiv: Muzychna Ukrayina [in Russian].

2. Alekseyev, A. (1978). Piano teaching methodology. Moskva: Muzyka [in Russian].

3. Bezborodko, O. (2012). Musical pronunciation and articulation as a composer's means of expressiveness. Visnyk of the Kharkiv State Academy of Design and Fine Arts, 15, 102-106 [in Russian].

4. Bezborodko, O. (2005). Features and evolution of the melodious interpretation of keyboard instruments from J.S. Bach to Romantics. Kyivske muzykoznavstvo: Kulturologiya ta mystetstvoznavstvo, 18, 211-221 [in Russian].

5. Documents of the life and work of J.S. Bach, (1980). H.J. Schulze (Eds.), V. Yerokhin (Transl.). Moskva: Muzyka [in Russian].

6. Kogan, G. (1971). Ferruccio Busoni: pianist. Moskva: Sovetsky kompozitor [in Russian].

7. Neygauz, G. (1961). On the art of piano playing: teacher's notes. Moskva: Gosudarstvennoye muzykalnoye izd-vo [in Russian].

8. Riabokoneva, M. (2016). Neoclassicism in music as a phenomenon of the modern West-European culture. Candidat's thesis. Kyiv [in Ukrainian].

9. Skrypnik, A. (2009). The phenomenon of aleatorics in the work of composers of the twentieth century: aesthetic-culturological aspect. Naukovyy visnyk of the NMAU, 75, 155-170 [in Russian].

10. Stepanchenko, H. (2015). Composer Igor Shcherbakov in the contemporary musical space. Ukrayinske muzykoznavstvo, 41, 362-368 [in Ukrainian].

11. Stepurko, V. (2013). „Concerto for flute and chamber orchestra (in memory of Oleh Kiva": artistic introversion. Mystetstvoznavchi zapysky, 24, 9-15 [in Ukrainian].

12. Kharchenko, Ye. (2011). Intertextuality in the Ukrainian music of the $20^{\text {th }}$ century: intonation, genre, style. Candidate's thesis. Kyiv [in Ukrainian].

13. Shcherbakov, I. (without year). I want to say a couple of words about „PianoGesang". Kyiv: Manuscript [in Ukrainian].

14. Rochberg, G. (1973). String Quartet No. 3: [liner note to LP record]. Nonesuch Records № 71283. 